ISSN 0103-5150

Fisioter. Mov., Curitiba, v. 27, n. 4, p. 505-514, out./dez. 2014

Licenciado sob uma Licença Creative Commons

DOI: http://dx.doi.org.10.1590/0103-5150.027.004.A002

\title{
Correlation between functional capacity and health- related quality of life in COPD: a case series
}

\author{
Correlação entre capacidade funcional e qualidade \\ de vida na DPOC: série de casos
}

\author{
Karina Maria Cancelliero-Gaiad ${ }^{[a]}$, Daniela Ike ${ }^{[b]}$, Liliana Soave ${ }^{[c]}$, \\ Evelim Leal de Freitas Dantas Gomes ${ }^{[\mathrm{d}]}$, Fernanda Dultra Dias ${ }^{[\mathrm{e}]}$, Dirceu Costa ${ }^{[\mathrm{f}]}$ \\ [a] PhD, Universidade Federal de São Carlos (UFSCar), São Carlos, SP - Brazil, e-mail: karina.gaiad@gmail.com \\ [b] PhD student at Universidade Federal de São Carlos (UFSCar), professor at Universidade Federal do Triângulo Mineiro, \\ Uberaba, MG - Brazil, e-mail: daniela.ike@gmail.com \\ [c] Undergraduate degree in Physical Therapy, Faculdade Anhaguera, Piracicaba, SP - Brazil, e-mail: li.soave@hotmail.com \\ [d] PhD student, Programa de Pós-Graduação em Ciências da Reabilitação, Universidade Nove de Julho (Uninove), professor \\ at Uninove, São Paulo, SP - Brazil, e-mail: evelimfreitas@hotmail.com \\ [e] PhD student, Programa de Pós-Graduação em Ciências da Reabilitação, Universidade Nove de Julho (Uninove), São Paulo, \\ SP - Brazil, e-mail: nandakiz@yahoo.com.br \\ [f] PhD, professor, Programa de Pós-Graduação em Ciências da Reabilitação, Universidade Nove de Julho (Uninove), São \\ Paulo, SP - Brazil, e-mail: dcosta@uninove.br
}

\section{Abstract}

Objective: To correlate functional capacity test scores from chronic obstructive pulmonary disease (COPD) subjects with their functional state as assessed by health-related quality of life questionnaires (one respiratory disease-specific [SGRQ] and one generic [SF-36] questionnaire). Materials and methods: Study of a case series of 8 COPD patients. The following tests were performed: 1) Six-minute walk test (6-MWT); 2) Shuttle walking test (SWT); 3) Six-minute step test (6-MST); 4) Two-minute sit-to-stand test (STST); and 5) Pegboard and ring test (PBRT). Besides these tests, two health-related quality of life questionnaires were administered: The St George's Respiratory Questionnaire (SGRQ) and the Short Form 36 (SF-36) health survey questionnaire. The statistical analysis was carried out by using the Shapiro-Wilk normality test, while correlations were assessed using Pearson's (parametric data) or Spearman's (non-parametric data) rank tests, with 
$\mathrm{p}<0.05$. Results: The 6-MWT showed strong correlation with the SF-36 scales of physical functioning, general health, vitality, social functioning and mental health. Conversely, the other functional capacity tests showed no correlation with this questionnaire. The SGRQ showed no correlation with any of the tests. Conclusions: The 6-MWT may be a good test to reflect the health-related quality of life of COPD subjects.

Keywords: Quality of life. COPD. Exercise test.

\section{Resumo}

Objetivo: Correlacionar as respostas de testes de capacidade funcional em indivíduos portadores de doença pulmonar obstrutiva crônica (DPOC) com o estado funcional avaliado de maneira subjetiva pelos questionários de qualidade de vida, sendo um específico para doença respiratória (SGRQ) e outro genérico (SF36). Materiais e métodos: Foi realizado um estudo de uma série de casos com oito pacientes portadores de DPOC que realizaram os seguintes testes: 1) Teste de caminhada de seis minutos (TC6'); 2) Shuttle walking test (SWT); 3) Teste do degrau de seis minutos (TD6'); 4) Teste de sentar e levantar-se da cadeira em dois minutos (TCad-2min); e 5) Pegboard and ring test (PBRT). Além dos testes, foram aplicados dois questionários de qualidade de vida: Hospital Saint George na doença respiratória (SGRQ) e o Short Form 36 (SF-36). A análise estatística foi realizada pelo teste de normalidade Shapiro-Wilk seguido dos testes de correlação de Pearson (dados paramétricos) ou de Spearman (dados não-paramétricos) com $p<0,05$. Resultados: Somente o TC6' mostrou forte correlação com o SF-36 nos aspectos físicos, estado geral de saúde, vitalidade, aspectos sociais e saúde mental, diferentemente dos outros testes de capacidade funcional que não mostraram correlação com este questionário. Com relação ao SGRQ, não houve correlação com nenhum dos testes. Conclusões: O TC6' pode ser um bom teste para refletir a qualidade de vida dos indivíduos portadores de DPOC.

Palavras-chave: Qualidade de vida. DPOC. Teste de esforço.

\section{Introduction}

Reduced exercise capacity is a common manifestation of chronic obstructive pulmonary disease (COPD). Patients with moderate to severe obstruction are often limited in their ability to perform even simple activities of daily living (ADLs), such as combing their hair or brushing their teeth (1). Exercise intolerance, tiredness and muscle fatigue are most often related to the lower limbs. However, patients with severe COPD have great difficulty maintaining their ability to perform ADLs due to tiredness and fatigue in the upper limbs. The elevation of the upper limb increases the consumption of oxygen and production of carbon dioxide, thereby reducing the participation of shoulder girdle muscles in the ventilation of patients with COPD (2).

In this context, some tests have been currently used for the clinical diagnosis of exercise capacity and for monitoring response and progress in pulmonary rehabilitation (PR) programs because they are considered to be a simple complementary tool.
These tests play a relevant role in clinical practice, as different studies recognize them as an essential part of the clinical assessment of patients with respiratory problems (3).

Since there is a great variety of functional capacity tests available for use in individuals with COPD, and no consensus in the literature about which of these tests has better correlation with health-related quality of life, further studies on this subject need to be conducted. This correlation is thus important, since health-related quality of life questionnaires are easy to administer and patients are often unable to perform functional capacity tests. The study hypothesis is that there is one test that is able to reflect the health-related quality of life (HRQoL) of individuals with COPD.

The objective of this study was to correlate functional capacity test scores from chronic obstructive pulmonary disease (COPD) subjects with their functional state as assessed by health-related quality of life questionnaires (one respiratory disease-specific [SGRQ] and one generic [SF-36] questionnaire). 


\section{Materials and methods}

\section{Sample}

The study sample comprised 8 subjects $(6$ men and 2 women) with clinical diagnosis of COPD (4). Inclusion criteria were: stable clinical condition; sedentary behavior; and body mass index (BMI) $<30 \mathrm{~kg} / \mathrm{m}^{2}$. Individuals older than 80 years of age $(\mathrm{n}=05)$, with a recent history of exacerbation $(\mathrm{n}=02)$, uncontrolled hypertension, cardiovascular $(n=02)$, neurological and/or osteoarticular $(n=02)$ disease precluding safe testing or who were undergoing home oxygen therapy $(n=01)$ were excluded from the sample.

All volunteers were instructed and informed about the study procedures, in accordance with the provisions of Resolution 196/96 of the National Health Council. An informed consent form was signed by each participant. The study was approved by the Research Ethics Committee of the institution, under protocol number 346/2010.

\section{Materials}

The following materials were used in this study: an evaluation form; the St George's Respiratory Questionnaire (SGRQ); the Short Form 36 (SF36) health survey questionnaire; a pulse oximeter (NONIN Onyx $\left.{ }^{\circledR} 9500\right)$; a heart rate monitor (Polar ${ }^{\circledR}$ ); a stopwatch (Cronobio ${ }^{\circledR}$ ); a modified Borg CR10 scale; a sphygmomanometer $\left(\mathrm{BD}^{\circledR}\right)$ and a stethoscope $\left(\mathrm{BD}^{\circledR}\right)$.

\section{Experimental procedure}

First, we assessed personal data, anthropometric data (weight, height, body mass index [weight/height $\mathrm{x}$ height]), lifestyle habits, and personal and family medical history of each subject.

Second, we administered two questionnaires to the subjects: the Medical Outcomes Study SF-36 (5), a generic, health-related quality of life questionnaire; and the Saint George Respiratory Questionnaire (SGRQ), a respiratory disease-specific questionnaire validated in Portuguese, which addresses aspects related to three domains of HRQoL that may be affected by the respiratory disease, namely: "Symptoms", "Activities" and "Psychosocial Impacts" (6).
Patients self-completed the questionnaires in the presence of the same interviewer. Doubts were clarified according to the administration manual.

Third, subjects underwent the following functional capacity tests, performed by a single evaluator: 1) Six-minute walk test (6-MWT); 2) Shuttle walking test (SWT); 3) Six-minute step test (6-MST); 4) Twominute sit-to-stand test (STST); and 5) Pegboard and ring test (PBRT).

Tests were performed randomly by lot. There was a rest period of 60 minutes between tests and no more than two tests were carried out per day (Figure 1).

\section{6-minute walk test (6-MWT)}

Following the recommendations of the American Thoracic Society (ATS), the test was performed on a 30-meter corridor, marked at every 3 meters. Individuals were asked to walk back and forth along the corridor as many times as possible in 6 minutes (7).

\section{Shuttle Walking Test (SWT)}

This test was performed on a 10-meter corridor. Patients were asked to walk between two cones 9 meters apart at an incrementally increasing pace. Each increment was signaled by a fully calibrated audiocassette and there were 12 speed levels (8).

\section{6-minute step test (6-MST)}

Patients were asked to step up and down, as quickly as possible, a 20 -cm platform, without using the upper limbs and alternating the lower limbs. If the patient was tired or short of breath, he/she was allowed to slow down or stop and rest, but was asked to resume the test as soon as possible. We recorded the number of times that the patient stepped onto the platform with both legs (9).

The following parameters were assessed in each of the three aforementioned tests: peripheral oxygen saturation $\left(\mathrm{SpO}_{2}\right)$, heart rate (HR), fatigue/pain in the lower limbs and sensation of dyspnea (modified Borg CR10 scale): Readings were recorded at rest and every 2 minutes during the test (at minutes 2,4 and 6 ), and in the test recovery period (at minutes 1, 3 and 
6 post-test). Blood pressure (BP) was measured at rest and during recovery.

Two-minute sit-to-stand test (STST)

We used a chair with backrest but no armrest. The subject was instructed to sit down on the chair and then stand up, fully extending the knees and producing no postural compensations. This procedure should be repeated as quickly and as often as possible for two minutes. Subjects were allowed to perform the test at their own pace (10). The number of full repetitions was recorded $(11,12)$. The following parameters were measured before and after the test: $\mathrm{SpO}_{2}$, HR, fatigue/pain in the lower limbs and sensation of dyspnea (modified Borg CR10 scale). BP measurements were performed while sitting during the rest and the recovery periods. $\mathrm{SpO}_{2}, \mathrm{HR}$, sensation of dyspnea and fatigue/pain in the lower limbs were measured at rest, at minutes 1 and 2 during the test and in the post-test recovery period (at minutes 1 and 3).

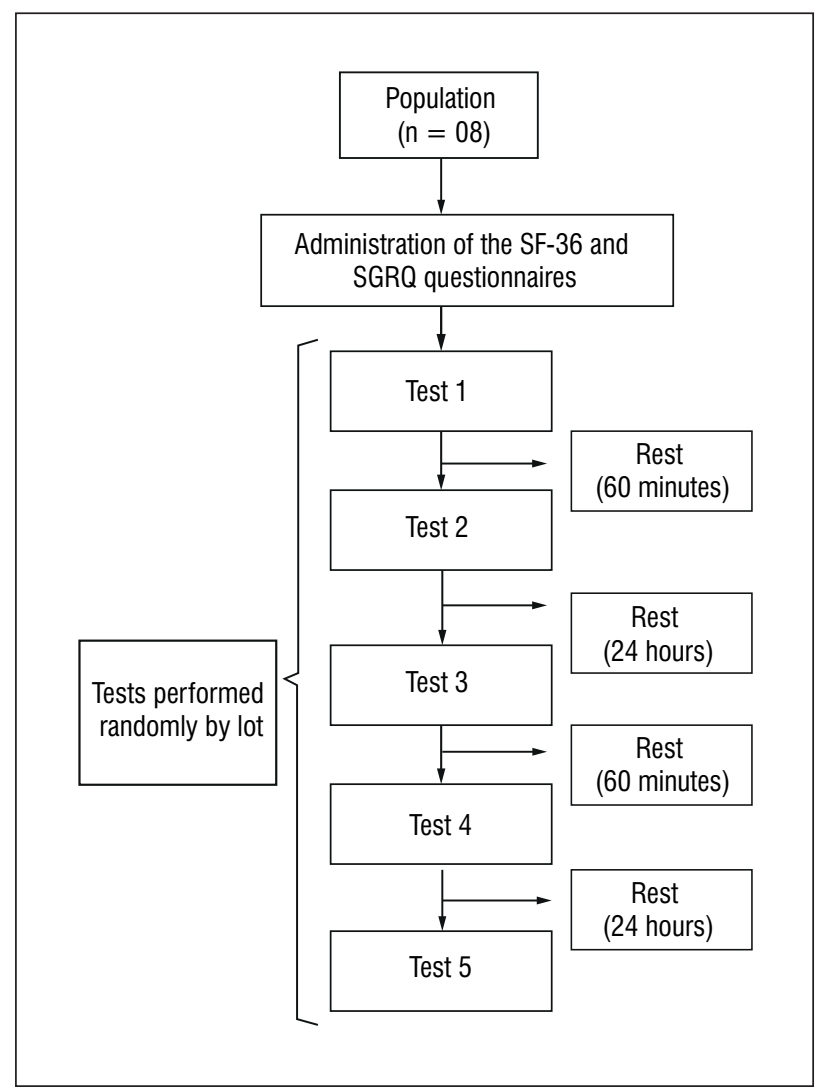

Figure $\mathbf{1}$ - Experimental protocol
Pegboard and Ring Test (PBRT)

The Pegboard and Ring Test (PBRT), developed by Celli et al. (13) and validated by Zhan et al. (14) measures unsupported endurance capacity of the upper limbs in individuals with COPD. For this test, subjects were seated in front of a pegboard with four pegs. Two pegs were set at the subjects' shoulder height and two were positioned $20 \mathrm{~cm}$ above. Ten rings were placed on each of the two lower pegs. Subjects were instructed to use both hands, start with the dominant hand and move one ring at a time from the lower to the upper peg. After moving all the rings from the lower to the upper pegs, the subjects had to move them back again to their original position and so on. Total test score was the number of rings moved in six minutes. The following parameters were analyzed: $\mathrm{SpO}_{2}, \mathrm{HR}, \mathrm{BP}$, sensation of dyspnea and fatigue/pain in the upper limbs (modified Borg CR10 scale). Measurements were made at rest and during the recovery period (minutes 1,3 and 6 post-test). $\mathrm{HR}$, sensation of dyspnea and fatigue/pain in the upper limbs were measured during the test at minutes 2,4 and 6.

The tests followed the recommendations provided by the ATS for the 6-MWT (7). Subjects were instructed to perform the tests as quickly as possible and to reduce the pace or interrupt the test in case of particular events, such as severe fatigue, dyspnea, desaturation $\left(\mathrm{SpO}_{2}\right.$ below $\left.90 \%\right)$, reaching the submaximal HR ( $85 \%$ of maximal HR) or other discomfort. The test should be resumed as soon as the subject was feeling more comfortable, and the stopwatch was kept running during the entire time limit. One week before the assessment, all patients performed the tests in order to get familiar with them.

\section{Statistical analysis}

The statistical analysis was carried out by using the Shapiro-Wilk normality test, while the correlation between functional capacity and healthrelated quality of life measured by SGRQ and SF-36 were assessed using Pearson's (parametric data) or Spearman's (non-parametric data) rank tests. We used the software Prism 5.0 and a significance level of 5\% $(\mathrm{p}<0.05)$. 


\section{Results}

The COPD group analyzed in this study consisted of 6 men and 2 women. Their characteristics are presented in Table 1 . Subjects with COPD were distributed as follows according to the obstructive ventilatory disorder: Mild: 1; Moderate: 1; Severe: 5; Very severe: 1 . With respect to smoking habits, 3 were smokers and 5 were ex-smokers.

Table 2 shows the results of the functional capacity tests performed.

All scores of the health-related quality of life tests SGRQ and SF-36 are presented as percentage, as shown in Table 3.

The correlation between the tests and the SGRQ and SF-36 questionnaires is shown in Table 4, and is represented by $r$. According to our findings, the 6-MWT showed strong correlation with the SF-36 scales of physical functioning, general health, vitality, social functioning and mental health. Conversely, the other functional capacity tests showed no correlation with this questionnaire The SGRQ showed no correlation with any of the tests.

\section{Discussion}

Only the 6-MWT results showed correlation with the functional state subjectively measured by the SF-36 health survey questionnaire in 5 out of 8 scales, namely: "physical functioning", "general health", "vitality", "social functioning" and "mental health". Conversely, the other functional performance tests showed no significant correlation with this questionnaire. The SGRQ a respiratory disease-specific questionnaire, showed no correlation with any of the tests measurements performed, except for the total score of the 6-MST.

Table 1 - Population characteristics $(n=8)$

\begin{tabular}{lc}
\hline Variable & \\
\hline Age (years) & $68.6 \pm 6.1$ \\
Weight $(\mathrm{kg})$ & $70.8 \pm 10.4$ \\
Height $(\mathrm{cm})$ & $1.6 \pm 0.1$ \\
$\mathrm{BMl}\left(\mathrm{kg} / \mathrm{m}^{2}\right)$ & $27.3 \pm 4.4$ \\
$\mathrm{SpO}_{2}$ & $95.5 \pm 1.9$ \\
$\mathrm{HR}(\mathrm{bpm})$ & $86.1 \pm 16.2$ \\
$\mathrm{SBP}(\mathrm{mmHg})$ & $123.8 \pm 10.6$ \\
$\mathrm{DBP}(\mathrm{mmHg})$ & $78.8 \pm 9.9$ \\
$\mathrm{FVC}$ & $76.3 \pm 10.6$ \\
$\mathrm{VEF}$ & $(\%$ predicted) \\
$\mathrm{VEF} / \mathrm{FVC}$ & $46.5 \pm 9.1$ \\
\hline
\end{tabular}

Note: Values are mean \pm standard deviation. $\mathrm{BMI}=$ body mass index; $\mathrm{SpO}_{2}=$ peripheral oxygen saturation; $\mathrm{HR}=$ heart rate; $\mathrm{SBP}=$ systolic blood pressure; DBP = diastolic blood pressure; FVC = forced vital capacity; $\mathrm{FEV}_{1}=$ Forced expiratory volume at one second; $\mathrm{FEV}_{1} /$ FVC $=$ Tiffeneau's ratio.

Table 2 - Functional capacity tests of the COPD group $(n=8)$ 
Table 2 - Functional capacity tests of the COPD group $(n=8)$

(Conclusion)

\begin{tabular}{ll}
\hline Test & \\
\hline 6-MST (number of times) & $107.4 \pm 36.2$ \\
PBRT (number of times) & $182.0 \pm 26.7$ \\
\hline
\end{tabular}

Note: Values are mean \pm standard deviation. 6-MWT $=$ six-minute walk test; SWT $=$ shuttle walking test; STST $=$ two-minute sit-to-stand test; 6 -MST = six-minute step test; PBRT = pegboard and ring test.

Table 3 - St George's Respiratory Questionnaire (SGRQ) and Short Form 36 health survey questionnaire scores of the COPD group $(n=8)$

\begin{tabular}{lc}
\hline SGRQ & $\%$ \\
\hline Symptoms & $31.4 \pm 29.2$ \\
Activities & $39.1 \pm 29.6$ \\
Impacts & $24.1 \pm 23.8$ \\
Total score & $29.9 \pm 24.2$ \\
\hline SF-36 & $\%$ \\
\hline Functional capacity & $64.4 \pm 28.5$ \\
Physical Functioning & $81.3 \pm 29.1$ \\
Bodily pain & $69.1 \pm 30.9$ \\
General health & $54.0 \pm 22.4$ \\
Vitality & $65.0 \pm 17.9$ \\
Social Functioning & $79.7 \pm 24.9$ \\
Role-Emotional & $79.2 \pm 39.6$ \\
Mental health & $71.5 \pm 29.7$ \\
\hline
\end{tabular}

Note: Values are mean \pm standard deviation.

Table 4 - Correlation between functional capacity tests and the SGRQ and SF-36 questionnaires for the COPD group $(n=8)$

(To be continued)

\begin{tabular}{lccccc}
\hline & 6-MWT & SWT & STST & 6-MST & PBRT \\
\cline { 2 - 6 } SGRQ & $\mathbf{r}$ & $\mathbf{R}$ & $\mathbf{r}$ & $\mathbf{r}$ & $\mathbf{r}$ \\
\hline Symptoms & -0.45 & -0.35 & -0.54 & -0.21 & -0.33 \\
Activities & -0.46 & -0.22 & -0.04 & -0.46 & -0.31 \\
Impacts & -0.69 & -0.44 & -0.11 & -0.57 & -0.24 \\
Total score & -0.52 & -0.56 & -0.20 & $-0.73^{*}$ & -0.28 \\
\hline & 6-MWT & SWT & STST & 6-MST & PBRT \\
SF-36 & $\mathbf{r}$ & $\mathbf{R}$ & $\mathbf{R}$ & $\mathbf{r}$ & $\mathbf{R}$ \\
\hline Functional capacity & $\mathbf{0 . 6 6}$ & 0.14 & 0.06 & 0.52 & 0.38
\end{tabular}


Table 4 - Correlation between functional capacity tests and the SGRQ and SF-36 questionnaires for the COPD group $(n=8)$

(Conclusion)

\begin{tabular}{lccccc}
\hline & 6-MWT & SWT & STST & 6-MST & PBRT \\
\cline { 2 - 6 } SF-36 & $\mathbf{r}$ & $\mathbf{R}$ & $\mathbf{R}$ & $\mathbf{r}$ & $\mathbf{R}$ \\
\hline $\begin{array}{l}\text { Physical } \\
\text { functioning }\end{array}$ & $0.88^{*}$ & 0.11 & 0.14 & 0.45 & 0.44 \\
Pain & 0.34 & -0.40 & -0.55 & -0.20 & 0.42 \\
General health & $0.84^{*}$ & 0.31 & 0.47 & 0.57 & 0.63 \\
Vitality & $0.75^{*}$ & 0.40 & 0.004 & 0.47 & 0.67 \\
Social functioning & $0.81^{*}$ & 0.60 & -0.16 & 0.70 & 0.17 \\
Role-Emotional & -0.22 & -0.74 & 0.19 & -0.46 & 0.31 \\
Mental health & $0.81^{*}$ & 0.15 & -0.28 & 0.41 & 0.42 \\
\hline
\end{tabular}

Note: Values correspond to $r$ (correlation); ${ }^{*} p<0.05 .6$-MWT $=$ six-minute walk test; SWT $=$ shuttle walking test; STST $=$ two-minute sit-to-stand test; 6-MST = six-minute step test; PBRT = peg board and ring test.

Chronic COPD symptoms such as dyspnea, wheezing, cough, sputum production, and exercise intolerance, together with anxiety and depression, are primarily responsible for altering the relationship between health and quality of life (QoL) (15). According to Jones et al. (16), QoL can be defined as "quantification of the impact of disease on daily life and well-being in a formal and standardized manner". Implicit in this concept is the importance of the role of standardized health-related QoL questionnaires, which allow the objective comparison of the impact of interventions used in COPD by means of absolute or percentage score values (17).

Although the objective of this study was to assess whether the results of any of the functional performance tests analyzed would correlate with the results of the SGRQ or SF-36 health-related quality of life questionnaire, the analysis of the impact of interventions through QoL questionnaires proves important.

Functional performance tests are important because they assess exercise capacity. In COPD, exercise intolerance has great implications for QoL, number of hospitalizations and survival (18). This study aimed to correlate functional performance tests with healthrelated QoL questionnaires, just as exercise intolerance is correlated with quality of life.

Submaximal tests are easy to perform, have low complexity and do not require costly equipments (18-20). Among the tests used in this study, the six-minute walk test (6-MWT) was the only one found to have correlation with the SF-36 questionnaire. Some studies have already reported that the 6-MWT reflects the exercise capacity to perform physical activities of daily living in patients with COPD (21-23).

The study by Nogueira et al. (24) aimed to correlate the SF-36 and Minnesota Living with Heart Failure (MLHFQ) QoL questionnaires with the functional capacity of patients with heart failure (HF), as measured by the cardiopulmonary exercise test and the 6-MWT. The results of this study showed a weak to moderate correlation between both QoL assessment instruments - the generic SF-36 and the disease-specific MLHFQ - and the cardiopulmonary exercise test and the 6-MWT scores. There was specifically a weak positive correlation $(r=0.4)$ only with the "Role-Emotional" scale. A study by Hamilton and Haennel (25) evaluated the quality of life of patients with cardiopulmonary diseases by using the SF-36 and correlated this questionnaire with the 6-MWT. They found a moderate positive correlation with the scale of "Physical functioning" ( $r=0.62)$. Thus, although our study was conducted with COPD patients, the test (6-MWT) and questionnaire (SF-36) used were the same as in the aforementioned study. Our study showed a strong correlation of the 6-MWT with the SF36 questionnaire, specifically with the scales of "Physical functioning" ( $\mathrm{r}=0.88)$, "General health" $(r=0.84)$, "Vitality" $(r=0.75)$, "Social functioning" $(r=0.81)$ and "Mental health" $(r=0.81)$. 
Pereira et al. (26) conducted a study with COPD patients (2009) and found no correlation between the 6-MWT and the SF-36 PSS (physical summary scale) and MHSS (mental health summary scale). However, differently from our study and from other studies discussed previously, these authors have used the summary scales instead of the eight individual scales. Bailey et al. (27) also found no correlation between the SF-36 and Shortness of Breath Questionnaire, and the 6-MWT.

Regarding the SGRQ, we found a few studies on the use of this questionnaire in COPD patients. Ketelaars et al. (28) found a low negative correlation between the 12-minute walk test and the domains of "Activities" $(r=-0.39)$ and "Impact" $(r=-0.36)$. According to these authors, this may indicate that patients with better scores the walk test have their activities less restricted and experience less impact of the disease on their daily lives. Mangueira et al. (29) also found a negative correlation $(r=-0.3677)$ between the distance covered in the 6-MWT and the "total" SGRQ score in women with COPD. Dourado et al. (30) also found a negative correlation with the domains of "Activities" ( $r=-0.58$ ) and "Impacts" ( $r=-0.63)$. The authors state that these results do seem to be one of the factors that influence the quality of life of patients with COPD, although the intensity of the relationship is not yet clear. They also point out that a better performance in the 6-MWT could mean less difficulty in performing daily physical activities and, therefore, smaller disease impact. Furthermore, these authors believe that the 6-MWT may be an important clinical indicator of functional capacity. We found a strong correlation between the 6-MWT and the SF-36 questionnaire. Regarding the SGRQ, we found a significant (negative) correlation only with the "total" 6-MWT score. This result indicates that the 6-MWT may be used in clinical practice to reflect the quality of life as measured by the SGRQ. However, as we only found a correlation with the "total score", and not with the individual variables, we suggest that further studies are conducted with this test. A similar result was observed by Dale et al. (31). These authors found that the 6-MWT was (negatively) correlated only with the "total" SGRQ score ( $r=-0.57)$.

Karapolat et al. (32) found a negative correlation between Borg's dyspnea scale and the functional capacity test SWT in a group of individuals with COPD. They also observed that Borg's dyspnea scale was negatively correlated with the scales of "Functional Capacity" and "Physical functioning". Although other variables are correlated, this was the only study that addressed the SWT and the SF-36. Regarding the other tests (PBRT, 6-MST and STST), although there are studies such as the ones by Ike et al. (33) on PBRT, and by Pessoa et al. (10) on 6-MST and STST, we found no studies analyzing the correlations of these tests with health-related quality of life.

\section{Conclusion}

Thus, according to the results observed in our study and in the studies found in the literature, there is a need for further research in this area, with an increased sample size (study limitation). Although the 6-MWT scores correlate with some aspects of QoL, there is no consensus among studies. There are several studies on the 6-MWT. However, further studies on other functional capacity tests are needed.

In conclusion, this study shows that only the 6-MWT was able to reflect the health-related quality of life of COPD subjects, which confirms the initial hypothesis.

\section{References}

1. Velloso M, Jardim JR. Study of energy expenditure during the activities of daily living using and not using body position recommended by energy conservation techniques in COPD patients. Chest. 2006;130(1):126-32.

2. Cavalheiro VL. Fisioterapia respiratória no paciente crítico. $3^{\underline{a}}$ ed. Barueri: Manole; 2010.

3. Vilaró J, Resqueti VR, Fregonezi GAF. Avaliação clínica da capacidade do exercício em pacientes com doença pulmonar obstrutiva crônica. Rev Bras Fisioter. 2008; 12(4):249-59.

4. Rabe KF, Hurd S, Anzueto A, Barnes PJ, Buist SA, Calverley P, et al. Global strategy for the diagnosis, management, and prevention of chronic obstructive pulmonary disease: GOLD executive summary. Am J Resp Crit Care Med. 2007;176(6):532-55.

5. Ciconelli RM, Ferraz MB, Santos WS, Meinão IM, Quaresma MR. Tradução para a língua portuguesa e validação do questionário genérico de avaliação de qualidade de vida SF-36 (Brasil SF-36). Rev Bras Reumatol. 1999;39(3):143-50. 
6. Souza TC, Jardim JR, Jones P. Validação do Questionário do Hospital de Saint George na Doença Respiratória (SGRQ) em pacientes portadores de doença pulmonar obstrutiva crônica no Brasil. J Pneumol. 2000;26(3):119-28.

7. American Thoracic Society. ATS Statement: guidelines for the six-minute walk test. Am J Respir Crit Care Med. 2002;166(1):111-7.

8. Revill SM, Morgan MD, Singh SJ, Williams J, Hardman AE. The endurance shuttle walk: a new field test for the assessment of endurance capacity in chronic obstructive pulmonary disease. Thorax. 1999;54(3):213-22.

9. Dal Corso S, Duarte SR, Neder JA, Malaguti C, Fuccio MB, Castro Pereira CA, et al. A step test to assess exercise-related oxygen desaturation in interstitial lung disease. Eur Respir J. 2007;29(2):330-6.

10. Pessoa BV, Basso RP, Regueiro EMG, Pires Di Lorenzo V, Costa D. Teste do degrau e teste da cadeira: comportamento das respostas metábolo-ventilatórias e cardiovasculares na DPOC. Fisioter Mov. 2012;25(1):105-15.

11. Ozalevli S, Ozden A, Itil O, Akkoclu A. Comparison of the sit-to-stand test with 6 min walk test in patients with chronic obstructive pulmonary disease. Respir Med. 2007;101(2):286-93.

12. Umeda IIK. Manual de fisioterapia na reabilitação cardiovascular. Barueri: Manole; 2005.

13. Celli BR, Rassulo J, Make BJ. Dyssynchronous breathing during arm but not leg exercise in patients with chronic airflow obstruction. N Engl J Med. 1986; 314(23):1485-90.

14. Zhan S, Cerny FJ, Gibbons WJ, Mador MJ, Wu YW. Development of an unsupported arm exercise test in patients with chronic obstructive pulmonary disease. J Cardiopulm Rehabil. 2006;26(3):1800-7.

15. Jones PW. Health status measurement in chronic obstructive pulmonary disease. Thorax. 2001;56(11): 880-7.

16. Jones PW, Quirk FH, Baveystock CM. The St George's Respiratory Questionnaire. Respir Med. 1991;85 (Suppl B):25-31. discussion 33-7.

17. Camelier A, Rosa FW, Salim C, Nascimento OA, Cardoso FC, Jardim JR. Using the Saint George's Respiratory Questionnaire to evaluate quality of life in patients with chronic obstructive pulmonary disease: validating a new version for use in Brazil. J Bras Pneumol. 2006;32(2):114-22.
18. Casas A, Vilaro J, Rabinovich R, Mayer A, Barberà JA, Rodriguez-Roisin R, et al. Encouraged 6-min walking test indicates maximum sustainable exercise in COPD patients. Chest. 2005;128(1):55-61.

19. Leung ASY, Chan KK, Sykes K, Chan KS. Reliability, validity, and responsiveness of a 2-min walk test to assess exercise capacity of COPD patients. Chest. 2006; 130(1):119-25.

20. Cataneo DC, Cataneo AJM. Acurácia do teste de escada utilizando o consumo máximo de oxigênio como padrão-ouro. J Bras Pneumol. 2007;33(2):128-33.

21. Pitta F, Troosters T, Spruit MA, Decramer PM, Gosselink R. Characteristics of physical activities in daily life in chronic obstructive pulmonary disease. Am J Respir Crit Care Med. 2005;171(9):972-7.

22. Balfour-Lynn IM, Prasad SA, Laverty A, Whitehead BF, Dinwiddie R. A step in the right direction: assessing exercise tolerance in cystic fibrosis. Pediatr Pulmonol. 1998;25(4):278-84.

23. Swinburn CR, Wakefield JM, Jones PW. Performance, ventilation, and oxygen consumption in three different types of exercise test in patients with chronic obstructive lung disease. Thorax. 1985;40(8):581-6.

24. Nogueira ID, Servantes DM, Nogueira PA, Pelcerman A, Salvetti XM, Salles F, et al. Correlation between quality of life and functional capacity in cardiac failure. Arq Bras Cardiol. 2010;95(2):238-43.

25. Hamilton DM, Haennel RG. Validity and reability of the 6-minute walk test in a cardiac rehabilitation population. J Cardiopulm Rehabilt. 2000;20(3):156-64.

26. Pereira EDB, Pinto R, Alcântara M, Medeiros M, Mota RMS. Influência dos parâmetros funcionais respiratórios na qualidade de vida de pacientes com DPOC. J Bras Pneumol 2009;35(8):730-6.

27. Bailey SP, Brown L, Bailey EK. Lack of relationship between functional and perceived quality of life outcomes following pulmonary rehabilitation. Cardiopulm Phys Ther J. 2008;19(1):3-10.

28. Ketelaars CAJ, Schlösser MAG, Mostert R, Abu-Saad HH, Halfens, RJG, Wouters EFM. Determinants of healthrelated quality of life in pacients with chronic obstructive pulmonary disease. Thorax. 1996;51(1):39-43. 
29. Mangueira NM, Viega IL, Mangueira MAMM, Pinheiro AN, Costa MRSR. Correlação entre parâmetros clínicos e qualidade de vida relacionada à saúde em mulheres com DPOC. J Bras Pneumol. 2009;35(3):248-55.

30. Dourado VZ, Antunes LCO, Carvalho LR, Godoy I. Influência de características gerais na qualidade de vida de pacientes com doença pulmonar obstrutiva crônica. J Bras Pneumol. 2004;30(3):207-14.

31. Dale MT, McKeough ZJ, Munoz PA, Corte P, Bye PT, Alison JA. Functional exercise capacity and healthrelated quality of life in people with asbestos related pleural disease: an observational study. BMC Pulm Med. 2013;13(1):1 [Epub ahead of print].

32. Karapolat H, Eyigor S, Atasever A, Zoghi M, Nalbantgil S, Durmaz B. Effect of dyspnea and clinical variables on the quality of life and functional capacity in patients with chronic obstructive pulmonary disease and congestive heart failure. Chin Med J. 2008;121(7):592-6.
33. Ike D, Jamami M, Marino DM, Ruas G, Pessoa BV, Di Lorenzo VAP. Efeitos do exercício resistido de membros superiores na força muscular periférica e na capacidade funcional do paciente com DPOC. Fisioter Mov. 2013;23(3):429-37.

Received: $12 / 07 / 2013$ Recebido: 07/12/2013

Approved: 07/15/2014 Aprovado: 15/07/2014 